\title{
Anti-Toxoplasma gondii and anti-Neospora caninum antibodies in sheep from Paraná state, South Brazil: prevalence and associated factors
}

\author{
Anticorpos anti-Toxoplasma gondii e anti-Neospora caninum em ovinos do \\ estado do Paraná, sul do Brasil: prevalência e fatores associados \\ Paulo Roberto Romanelli*; Andressa Maria Rorato Nascimento de Matos ${ }^{1}$; Fernanda Pinto- \\ Ferreira1; Eloiza Teles Caldart"; João Lucas Moura do Carmo ${ }^{1}$; Nathalia Gomes dos Santos'; \\ Natalia Ribeiro da Silva'; Barbara Barcellos Loeffler ${ }^{1}$; João Fernando Zamariola Sanches ${ }^{1}$; \\ Luiza Schumacher Francisquini'; Micheline Sahyun Romanelli2; Alessandro Pelegrine Minho ${ }^{3}$; \\ Antônio Cezar Rocha Cavalcante; Elzira Jorge Pierre4; Claudio Cesar Sobezak4; Roberta Lemos Freire"; \\ Regina Mitsuka-Breganó ${ }^{\prime}$; Italmar Teodorico Navarro' ${ }^{10}$
}

\author{
${ }^{1}$ Departamento de Medicina Veterinária Preventiva, Universidade Estadual de Londrina - UEL, PR, Brasil \\ 2 Universidade Filadélfia - UNIFIL, Londrina, PR, Brasil \\ ${ }^{3}$ Empresa Brasileira de Pesquisa Agropecuária - EMBRAPA, Bagé, RS, Brasil \\ ${ }^{4}$ Agência de Defesa Agropecuária do Paraná - ADAPAR, Curitiba, PR, Brasil
}

\begin{abstract}
How to cite: Romanelli PR, de Matos AMRN, Pinto-Ferreira F, Caldart ET, do Carmo JLM, dos Santos NG, et al. Anti-Toxoplasma gondii and anti-Neospora caninum antibodies in sheep from Paraná state, South Brazil: prevalence and associated factors. Braz
\end{abstract} J Vet Parasito/ 2021; 30(1): e023220. https://doi.org/10.1590/S1984-29612021021

\begin{abstract}
The aim of this study was to evaluate the seroprevalence and factors associated with the presence of antiToxoplasma gondii and anti-Neospora caninum antibodies in sheep from Paraná state. The detection of antibodies for T. gondii and N. caninum was performed by homemade and commercial indirect ELISA, respectively. Multiple logistic regression analysis was used to verify the factors associated with the seroprevalence. Antibodies anti- $T$. gondii and anti-N. caninum were observed in $42.7 \%$ and in $17.6 \%$ of the animals, respectively. The protective factors associated to seropositive were "some level of confinement" (full or semi-extensive confinement) $(O R=0.53)$ for T. gondii and "use of skilled labor" $(\mathrm{OR}=0.64)$ for $N$. caninum. The risk factors were "presence of cats" $(O R=1.75)$ for $T$. gondii and "feeding of dogs with sheep placental remains" (OR=1.79) for N. caninum. In addition, to presenting a significant and simultaneous seroprevalence for both agents (9.9\% of the animals), the results also indicate that deficiencies in management and environmental sanitation, the presence of reservoirs, and types of exploitation enhance the seropositivity. Thus, studies like this might support sanitary programs and public policies for the prevention of $T$. gondii and $N$. caninum in the sheep herds of Paraná state.
\end{abstract}

Keywords: Seroprevalence, Toxoplasma gondii, Neospora caninum, sheep, Parana state, Brazil, ELISA.

\begin{abstract}
Resumo
O objetivo deste estudo foi avaliar a soroprevalência e os fatores de risco associados à presença de anticorpos contra Toxoplasma gondii e Neospora caninum em ovinos do Paraná. A detecção dos anticorpos para T. gondii e N. caninum foi realizada, usando-se testes de ELISA indireto caseiro e comercial, respectivamente. A análise de regressão logística múltipla foi usada para verificar os fatores de risco associados à soroprevalência. Anticorpos anti-T. gondii e anti-N. caninum foram observados em $42,7 \%$ e em $17,6 \%$ dos animais, respectivamente. Os fatores de proteção associados à soropositividade foram "algum nível de confinamento (confinamento ou semiextensivo)" $(O R=0,53)$ para T. gondii e "presença de mão de obra especializada" para N. caminum (OR=0,64). Os fatores de risco foram "presença de gatos" para $T$. gondii $(\mathrm{OR}=1,75)$ e "alimentação de cães com resíduos placentários" $(\mathrm{OR}=1,79)$ para $N$. caninum. Além de apresentar uma significante e simultânea soroprevalência para ambos os agentes (9,9\% dos animais), os resultados também indicam que as deficiências em gestão e saneamento ambiental, a presença de reservatórios e os tipos de exploração favorecem a soropositividade. Dessa forma, estudos como estes podem auxiliar em programas sanitários e políticas públicas para a prevenção de T. gondii e N. caninum nos rebanhos ovinos do Paraná.
\end{abstract}

Palavras-chave: Soroprevalência, Toxoplasma gondii, Neospora caninum, ovelha, estado do Paraná, Brasil, ELISA. 


\section{Introduction}

Toxoplasma gondii and Neospora caninum, protozoan extensively studied, are the main agents responsible for reproductive damage in sheep, goat, and bovine herds (Dubey \& Lindsay, 1996; Moreno et al., 2012). Seroprevalence of 33.8\% for T. gondii was verified in Brazilian sheep (Lugoch et al., 2019). In Paraná state was observed a mean seroprevalence of 35.9\% (7.0\%-51.8\%) in the last decades (Ogawa et al., 2003; Moura et al., 2007; Romanelli et al., 2007; Soccol et al., 2009; Gheller et al., 2016).

The seroprevalence (9.5\%) for Neospora caninum in the sheep in Paraná state was first described in 2007 in the herds from Guarapuava, Central-Southern region of the state (Romanelli et al., 2007). Almost ten years later, the seroprevalence in the same city was 3.7\%, showing the still presence of the protozoan in the region (Gheller et al., 2016).

The national sheep herd was estimated at 19,715,587 million heads (IBGE, 2019). According to the register of herds of the Secretariat of Agriculture and Supply, Paraná occupies the eighth position in the nation, with approximately 556.512 thousand heads, representing 2,9\% of the Brazilian herd (Paraná, 2019). Considering the lack of information and monitoring of both protozoan and the economic importance of the sheep herds to the Paraná state, it is necessary more studies that might contribute to the updating of SEAB database and which supports future actions to control. Thus, this study aimed to evaluate the seroprevalence of anti-T. gondii and anti-N. caninum IgG antibodies and the associated risk factors in the sheep herds of the Paraná state, southern Brazil.

\section{Material and Methods}

The study is part of the EMBRAPA project "Zoosanitary characterization of goat and sheep farming in Brazil: epidemiology, risk factors, and economic impacts of diseases" and was approved by the Ethics Committee for Animal Use of the same institution (number 010/2014).

It was chosen representative sheep farms from the mesoregions: Central-North, Metropolitan of Curitiba, West, Southwest, and Center-South. To calculate the sample size (n), the OPEN EPI (v3) program was used. For both studied agents, a 95\% confidence level, a 1.5 DEFF and an infinite population were adopted. A prevalence of $50.0 \%$ and an error of $2.5 \%$ were estimated for $T$. gondii, reaching the number of 1534 sampled animals. For N. caninum, a prevalence of $9.5 \%$ and an error of $1.5 \%$ were estimated, reaching up to the number 1,466 sampled animals. Sampling was performed by cluster; that is, within each property, the animals were stratified according to their categories, with approximately $60 \%$ of female breeders, $35 \%$ of the young (six to twelve months) and all male breeders randomly collected by visiting the property, for a total of 20 sheep.

Information about each property from 24 municipalities and their animals were obtained using a questionnaire. The information (126 questions) raised was - infrastructure, characteristics of production and commercialization, technological profile, sanitation, presence of other species on the property (domestic and/or wild) sex, age, and breed of the animals (Romanelli et al., 2020). Due to the great number of variables evaluated (questions), the authors opted to describe in the Results only those statically significant in the univariate analysis.

In each visited property during 2016, blood sample of 20 animals (a total of 1,609 sheep) was obtained by jugular puncture, collected in a tube without anticoagulant, and the serum obtained after centrifugation were kept ate $-4^{\circ} \mathrm{C}$ until analysis. The detection of anti-T gondii IgG antibodies was performed by the indirect ELISA technique as described by Garcia et al. (2007). The optimal conditions for the antigen concentration, serum titration and conjugate dilution were established by the highest ratio of the mean absorbance of positive samples to the mean absorbance of negative samples. The standardized $T$. gondii antigen concentration was $2.5 \mu \mathrm{g} \mathrm{mL}-1$, the sera were diluted to 1:100, and the conjugate anti-sheep IgG antibodies (Sigma Aldrich, USA ${ }^{\circledR}$ ) was diluted to 1:4,000. All samples were tested in duplicate. The cutoff point of each plate was obtained according to Garcia et al. (2006), using the mean value of optical densities of the negative controls plus three standard deviations. For detection of the anti-N. caninum antibodies, commercial indirect ELISA kits (ELISAi - IMUNODOT ${ }^{\circledR}$, Jaboticabal, Brazil) were used. The cutoff index $(\mathrm{Cl})$ was calculated by averaging the optical density of the negative controls multiplied by the factor 2.5. Positive samples were found to have a bright yellow color and an optical density equal to or greater than the $\mathrm{Cl}$, as described by the manufacturer.

The Epilnfo 7.1.5.2 program (Dean et al., 1996) was used to tabulate the variables that made up the epidemiological questionnaire along with the serological results. The variables of the epidemiological questionnaire were analyzed by a Yates-corrected chi-square test and Fisher's exact test. Those with $p<0.05$ were selected for multiple logistic 
regression analysis, and the association strength was measured using the odds ratio (OR) values and the respective 95\% confidence interval. The properties were mapped using a global positioning system (GPS). Shapefiles were built using the ArcGIS $®$ program (ESRI, 2011). The point distribution and kernel density were built using QGIS.

\section{Results and Discussion}

The study covered six of ten mesoregions in Paraná state, including 80 rural properties distributed in 24 municipalities (Figure 1), totaling 1609 animals. In all mesoregions studied, 92.5\% (74/80) and 80.0\% (64/80) of the properties showed animals $T$. gondii and $N$. caninum seroreactive, respectively (Table 1). For T. gondii, all the regions, except the metropolitan one (26.2\%), had seropositivity close to or greater than $50 \%$ (40.7 - 72.1\%), and the largest being in the Central-Northern mesoregion (Table 1). Whereas for $N$. caninum, the prevalence was smaller (7.5-32.7\%), with a major rate of positivity in the Central-Eastern region (Table 1). Presence of positive animals for both protozoan was observed in $75.0 \%$ (60/80) of the studied properties. It is important to highlight that the present study showed the prevalence in most of the mesoregions of Paraná state, differently of previous studies that represented fewer regions. In addition, these results demonstrated the existence of favorable conditions for the spread of both agents in sheep in whole Paraná state.

The prevalence of anti-T. gondii IgG antibodies in sheep was 42.7\% (688/1609; 95\% Cl 40.36-45.19). Studies on the occurrence or prevalence of toxoplasmosis in sheep in Paraná have been performed by other authors. The occurrence in the northern region of Paraná ranged from 47.8 to 54.6\% (Ogawa et al., 2003; Garcia et al., 1999) and from 40.7 to $51.5 \%$ in the midwestern region (Romanelli et al., 2007; Gheller et al., 2016).

A recent review reported 196 studies around the world (2009-2020) and approximately $45 \%$ of then used ELISA assays to detect anti-T. gondii antibody in sheep (Dubey et al., 2020). The higher occurrence was observed in Parma, Italy (100\%) (Vismarra et al., 2017), El Fayoum and Assiut, Egypt (98 and 86\%, respectively) (Ghoneim et al., 2010; Kuraa \& Malek, 2016), Montserrat, Caribbean islands (89.3\%) (Hamilton et al., 2014), and in Nationwide, Belgium (75.7\%) (Verhelst et al., 2014). In the South Atlantic, only one study showed a prevalence of $41.1 \%$ in sheep from Several, Costa Rica (Villagra-Blanco et al., 2019).

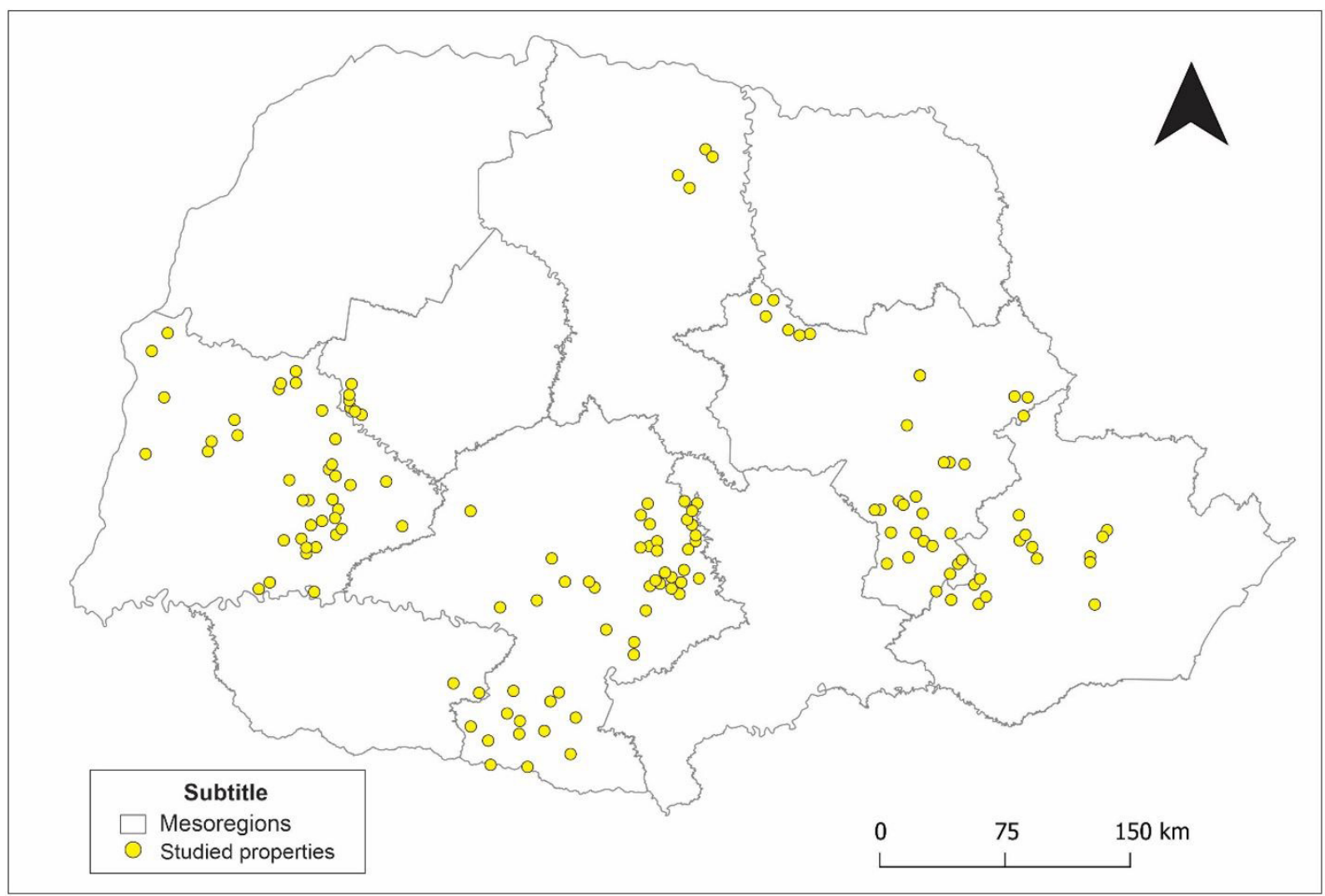

Figure 1. Local (studied properties) of sheep blood collection in the Paraná state, southern Brazil, to evaluate the occurrence of antibodies anti-Toxoplasma gondii and anti-Neospora caninum. 
Table 1. Frequencies of anti-Toxoplasma gondii and anti-Neospora caninum IgG antibodies (indirect ELISA) on sheep and on sheep breeding properties in six mesoregions of Paraná state, Brazil - 2016.

\begin{tabular}{ccccc}
\hline Mesoregion & $\begin{array}{c}\text { T. gondii Property } \\
\text { Positive/Total (\%) }\end{array}$ & $\begin{array}{c}\text { T. gondii Animals } \\
\text { Positive/Total (\%) }\end{array}$ & $\begin{array}{c}\text { N. caninum Property } \\
\text { Positive/Total (\%) }\end{array}$ & $\begin{array}{c}\text { N. caninum Animals } \\
\text { Positive/Total (\%) }\end{array}$ \\
\hline Western & $18 / 19(94.7)$ & $154 / 387(39.8)$ & $14 / 19(73.7)$ & $49 / 387(12.7)$ \\
Southeast & $8 / 8(100.0)$ & $81 / 170(47.6)$ & $7 / 8(87.5)$ & $13 / 169(7.7)$ \\
Central-Southern & $19 / 22(86.4)$ & $168 / 419(40.1)$ & $14 / 22(63.6)$ & $43 / 419(10.3)$ \\
Central-Eastern & $21 / 23(91.3)$ & $214 / 453(47.2)$ & $22 / 23(95.6)$ & $148 / 453(32.7)$ \\
Central-Northern & $3 / 3(100.0)$ & $34 / 60(56.7)$ & $3 / 3(100.0)$ & $13 / 60(21.7)$ \\
Metropolitan & $5 / 5(100.0)$ & $26 / 100(26.0)$ & $4 / 5(80.0)$ & $13 / 99(13.1)$ \\
Total & $\mathbf{7 4 / 8 0 ( 9 2 . 5 )}$ & $\mathbf{6 8 8 / 1 6 0 9 ( 4 2 . 7 )}$ & $\mathbf{6 4 / 8 0 ( 8 0 . 0 )}$ & $\mathbf{2 8 3 / 1 6 0 7 ( 1 7 . 6 )}$ \\
\hline
\end{tabular}

In Brazil, most part of the studies used indirect fluorescent antibody test (IFAT) as a diagnose method (28/34) (Dubey et al., 2020). Considering studies that use iELISA to detect anti-T. gondii antibodies was observed a mean prevalence of $44.8 \%$ (22.1-67.5\%) (Dubey et al., 2020) and the higher prevalence (67.5\%) was observed in Teresina, Piauí state (Rêgo et al., 2016). Thus, the seroprevalence to T. gondii found in the present study, in Paraná state, were similar to those observed in other Brazilian states.

The seroprevalence to N. caninum in the sheep of the present study was $17.6 \%$ (283/1607; 95\% Cl 15.83-19.55). In previous studies on Paraná state were observed occurrences of 3.7\% (3/81) (Gheller et al., 2016) and 9.5\% (29/305) (Romanelli et al. (2007) in the Central-Southern region of the state. In compare with our study, the Central-Southern region had $21.7 \%$ of seropositivity (Table 1 ). The higher seroprevalence might be due to the number of animals and properties in the present study.

It was observed that $9.9 \%(160 / 1607)$ of the animals were positive for both agents concurrently. Thus, control measures should be directed at both agents on most sheep farming properties of the state of Paraná.

The evaluations of the management, production, reproduction, and environmental characteristics with the results of the presence of anti-T. gondii and anti-N. caninum IgG antibodies are shown in the Tables 2 and 3, respectively.

The variables age, sex, use of skilled labor on the property, production system with some level of confinement, adequate food storage facilities, water supplied in off-site installations, and presence of cats on the property showed significant associations with a higher chance of seropositivity for $T$. gondii in the univariate analysis. Other variables evaluated, such as abortion, did not have statistical significance in the seroprevalence. Thus, those do not were shown in the text.

According to revision by Dubey et al. (2020), age, breed, geographic location, rainfall, flock size, grazing area, climate, and farm management might influence on the prevalence of $T$. gondii in sheep. The model obtained in the multiple logistic regression analysis that best explained the data behavior for $T$. gondii contained the variables "production system with some level of confinement" $(p<0.0001)$ and the "presence of cats on the property" $(p<0.0001)$. The last variable increased the chance of sheep being seropositive for toxoplasmosis by 1.75 -fold; on the other hand, the "production systems with some level of confinement (full confinement or semi-extensive confinement)" were found to be a protective factor against $T$. gondii infection (OR $=0.53$ ) (Table 2 ).

The variables that were significantly associated $(p<0.05)$ with the highest chance of seropositivity to $N$. caninum in the univariate analysis were age (higher than one year; OR 1.78), sex (OR 2.60), free access of animals to water sources (OR 1.36), water supplied in off-site containers (OR 2.08), use of skilled labor on the property (OR 0.69), and feeding dogs with placental remains of sheep (OR 1.71) (Table 3).

For N. caninum the multiple logistic regression model that best explained the prevalence are the variable "use of skilled labor" ( $p=0.0025)$ as a protective factor against $N$. caninum infection $(O R=0.64)$ and "feeding of dogs with sheep placental remains" ( $p=0.0001)$ as a risk factor that increased the chance of the animal being seropositive by 1.79 - fold.

To prevalence of $N$. caninum in older animals might be more likely to infection due to longer exposure to agents in the environment, as reported by many studies (Jittapalapong et al., 2005; Pinheiro et al., 2009; Anderlini et al., 2011; Díaz et al., 2014). On the other hand, Arraes-Santos et al. (2016) reported a 3.7 higher probability of occurrence of 
Table 2. Results of logistic regression analysis of the management, production and reproductive factors associated with seroreactivity for Toxoplasma gondii in sheep from Paraná state, Brazil.

\begin{tabular}{|c|c|c|c|c|c|}
\hline \multirow{3}{*}{ Variables } & \multirow{3}{*}{ Positive/total (\%) } & \multicolumn{2}{|c|}{ Univariate } & \multicolumn{2}{|c|}{ Multiple logistic regression } \\
\hline & & \multirow{2}{*}{$\mathbf{p}$} & OR & \multirow{2}{*}{$\mathbf{p}$} & Adjusted OR \\
\hline & & & (CI 95\%) & & (Cl 95\%) \\
\hline \multicolumn{6}{|l|}{ Age range (>1 year) } \\
\hline Yes & $286 / 524(54.6)$ & $<0.0001$ & 2.98 & UR & \\
\hline No & $119 / 415(28.7)$ & & $(2.27-3.92)$ & & \\
\hline \multicolumn{6}{|l|}{ Sex } \\
\hline Female & $366 / 809(45.2)$ & 0.0015 & 1.92 & UR & \\
\hline Male & $39 / 130(30.0)$ & & $(1.29-2.87)$ & & \\
\hline \multicolumn{6}{|l|}{ Skilled labor } \\
\hline Yes & $244 / 640(38.1)$ & 0.0067 & 0.74 & 0.1471 & \\
\hline No & $400 / 885(45.2)$ & & $(0.60-0.91)$ & & \\
\hline \multicolumn{6}{|l|}{ Production system } \\
\hline $\begin{array}{l}\text { Confinement } \\
\text { semi-confinement }\end{array}$ & $261 / 725(36.0)$ & $<0.0001$ & $\begin{array}{c}0.54 \\
(0.44-0.68)\end{array}$ & $<0.0001$ & $\begin{array}{c}0.53 \\
(0.42-0.66)\end{array}$ \\
\hline Extensive & $346 / 684(50.6)$ & & & & \\
\hline \multicolumn{6}{|c|}{ Adequate food storage facilities } \\
\hline Yes & $470 / 1129(41.6)$ & 0.0043 & 0.71 & 0.4539 & \\
\hline No & $210 / 421(49.9)$ & & $(0.57-0.89)$ & & \\
\hline \multicolumn{6}{|c|}{$\begin{array}{l}\text { Water provided supplied in off-site } \\
\text { installations }\end{array}$} \\
\hline Yes & $464 / 968(47.0)$ & 0.0010 & 2.07 & UR & \\
\hline No & $430 / 100(30.0)$ & & $(1.32-3.23)$ & & \\
\hline \multicolumn{6}{|l|}{ Cats on the property } \\
\hline Yes & 449/968 (46.3) & 0.0015 & 1.42 & $<0.0001$ & 1.75 \\
\hline No & 197/522 (37.7) & & $(1.14-1.77)$ & & $(1.38-2.21)$ \\
\hline
\end{tabular}

p:p value; OR: odds ratio; Cl: confidence interval; UR: unrealized - variable not included in the multiple logistic regression analysis due to a loss of questionnaire filling greater than $20 \%$.

$N$. caninum in young animals when compared to that of adult animals. Although in the horizontal transmission of neosporosis the time of exposure of the animals (age) to sources of infection is very important, this factor is less relevant in vertical transmission, so the higher prevalence in young animals might be easily accepted in properties where vertical transmission is more important than horizontal transmission. The fact that females are kept in the herd longer when compared to males, which are slaughtered earlier, justifies the greater exposure of these animals and consequently the higher seroprevalence. However, Uzêda et al. (2004) suggested greater susceptibility of females due to decreased immunity during pregnancy and lactation.

Regarding the age and sex of the animals there was a significant association for both agents. The variable "use of skilled labor" was significantly associated with seropositivity for both agents studied, proving to be a protective factor. The importance of skilled labor is discussed by Viana \& Silveira (2009), who studied the profile of sheep farming in the southern half of Rio Grande do Sul. According to the authors, specialized technicians follow up on sick animals; however, the permanent workforce in the properties do not exclusively work with sheep, and thus, 
Table 3. Results of logistic regression analysis of the management, production and reproductive factors associated with seroreactivity for Neospora caninum in sheep from Paraná state, Brazil.

\begin{tabular}{|c|c|c|c|c|c|}
\hline \multirow{3}{*}{ Variables } & \multirow{3}{*}{ Positive/total (\%) } & \multicolumn{2}{|c|}{ Univariate } & \multicolumn{2}{|c|}{ Multiple logistic regression } \\
\hline & & \multirow{2}{*}{$\mathbf{p}$} & OR & \multirow{2}{*}{$\mathbf{P}$} & Adjusted OR \\
\hline & & & (Cl 95\%) & & (Cl 95\%) \\
\hline \multicolumn{6}{|l|}{ Age range (>1 year) } \\
\hline Yes & $138 / 524(26.3)$ & 0.0004 & 1.78 & UR & \\
\hline No & $69 / 414(16.7)$ & & $(1.29-2.47)$ & & \\
\hline \multicolumn{6}{|l|}{ Sex } \\
\hline Female & $193 / 808(23.9)$ & 0.0012 & 2.60 & UR & \\
\hline Male & $14 / 130(10.8)$ & & $(1.45-4.63)$ & & \\
\hline \multicolumn{6}{|l|}{ Free access to water sources } \\
\hline Yes & $165 / 841$ (19.6) & 0.0230 & 1.36 & 0.1324 & \\
\hline No & $113 / 746(15.2)$ & & $(1.05-1.77)$ & & \\
\hline \multicolumn{6}{|c|}{ Water provided supplied in off installations } \\
\hline Yes & $185 / 984(18.8)$ & 0.0400 & 2.08 & UR & \\
\hline No & $10 / 100(10.0)$ & & $(1.06-4.08)$ & & \\
\hline \multicolumn{6}{|l|}{ Skilled labor } \\
\hline Yes & $94 / 639$ (14.7) & 0.0106 & 0.69 & 0.0025 & 0.64 \\
\hline No & 176/884 (19.9) & & $(0.52-0.91)$ & & $(0.48-0.85)$ \\
\hline \multicolumn{6}{|c|}{ Feeding of dogs with sheep placental remains } \\
\hline Yes & $100 / 426(23.5)$ & 0.0001 & 1.71 & 0.0001 & 1.79 \\
\hline No & $164 / 1080(15.2)$ & & $(1.29-2.26)$ & & $(1.34-2.38)$ \\
\hline
\end{tabular}

p:p value; OR: odds ratio; Cl: confidence interval; UR: unrealized - variable not included in the multiple logistic regression analysis due to a loss of questionnaire filling greater than $20 \%$.

the constant technical orientation of the employees has an impact on the adoption of good production practices, leading to abandonment and a gradual increase in the need to hire new laborers.

The more technologically advanced production systems, the full confinement and semi-confinement systems, when compared to the extensive system, presented as protective factors against the occurrence of $T$. gondii seropositivity. The observed data were corroborated by Pinheiro et al. (2009) when they found that sheep farming properties where the production systems were extensive presented 2.3-fold greater chances of occurrence of toxoplasmosis when compared to those where the system was intensive. However, Gazzonis et al. (2016) observed that properties that adopted semi-extensive production systems presented a 3.5-fold higher probability of occurrence of ovine neosporosis. As described by Dubey \& Schares (2011), in the semi-extensive production system, animals were supplemented with fodder and grains, which were stored in barns that were easily accessible to dogs, a practice that poses a high risk of infection.

Cats on farms often have free access to pastures, livestock facilities, food and supplement stores, and water sources and reservoirs, where they can eliminate $T$. gondii oocysts when defecating. The presence of cats on the properties is the main factor of environmental contamination and, consequently, of infection in humans and animals (Weigel et al., 1999). For the free access of animals to natural sources of water and the supply of water to animals in containers outside the premises, the possibility of contamination occurs due to the access of dogs and cats to these areas. Gondim et al. (2005) showed that dogs can eliminate N. caninum oocysts more than once in their lives, contaminating food and water. Cavalcante et al. (2008) found that $T$. gondii infection is associated with the low frequency of sanitation measures for goat drinkers in Ceará state and emphasized the impossibility of 
the sanitation of the facilities used for capturing and storing large volumes of water, which thus become modes of transmission to animals.

Although the dog is the definitive host of $N$. caninum, the variable presence of dogs on the properties was not significantly associated with seropositivity for this parasite; the presence of dogs was even observed on $71.4 \%$ of the properties (60/84). In Brazil, there is a cultural practice of feeding dogs with viscera from slaughtered sheep or placental remains, which may contain parasites and infect dogs, which in turn end up in feces, thereby contaminating the environment. Dubey et al. (2007) warned against the implementation of preventive measures to combat neosporosis, such as restricting the access of dogs to the areas of production animals and the correct disposal of placental remains.

Toxoplasma gondii is known to cause fetal resorption, miscarriages, and neonatal deaths of lambs and has been pointed out as the main parasite responsible for abortion in sheep and goats (Buxton et al., 2007, Moreno et al., 2012). In the present study, the occurrence of abortion on the property was not statistically associated with seropositivity for $T$. gondii or $N$. caninum, suggesting that the causes of abortion on these properties may not be the studied parasites or may be from other factors in conjunction with them. Approximately in 1.4 to $3.9 \%$ of the world's sheep flocks are losses due to reproductive effects, mainly abortion, associated with toxoplasmosis during pregnancy (Freyre et al., 1999). However, it is known that females that had abortion on account of $T$. gondii infection might also have protection against future reproductive problems due toxoplasmosis (Dubey et al., 2020). In another study at Paraíba state, northeast of Brazil, it was observed that around $50 \%$ of the sheep herd was seronegative at the age of 1 year, period of the first pregnancy (Valencio et al., 2020), making it highly susceptible to reproductive problems caused by this parasite.

The study conducted allowed the knowledge of the T. gondii and N. caninum distribution in the state of Paraná in sheep, with a higher prevalence of toxoplasmosis. The study of the variables associated with these parasites allowed us to characterize the deficiencies of environmental management and sanitation, the presence of reservoirs and the types of exploitation. It can also be used to support health programs and as a basis for future public policies related to the prevention of $T$. gondii and $N$. caninum.

\section{References}

Anderlini GA, Mota RA, Faria EB, Cavalcanti EF, Valença RM, Pinheiro Júnior JW, et al. Occurrence and risk factors associated with infection by Toxoplasma gondii in goats in the State of Alagoas, Brazil. Rev Soc Bras Med Trop 2011; 44(2): 157-162. http://dx.doi. org/10.1590/S0037-86822011005000017. PMid:21503550.

Arraes-Santos Al, Araújo AC, Guimarães MF, Santos JR, Pena HFJ, Gennari SM, et al. Seroprevalence of anti-Toxoplasma gondii and anti-Neospora caninum antibodies in domestic mammals from two distinct regions in the semi-arid region of Northeastern Brazil. Vet Parasitol Reg Stud Reports 2016; 5: 14-18. http://dx.doi.org/10.1016/j.vprsr.2016.08.007. PMid:31014531.

Buxton D, Maley SW, Wright SE, Rodger S, Bartley P, Innes EA. Toxoplasma gondii and ovine toxoplasmosis: new aspects of an old story. Vet Parasitol 2007; 149(1-2): 25-28. http://dx.doi.org/10.1016/j.vetpar.2007.07.003. PMid:17686585.

Cavalcante ACR, Carneiro M, Gouveia AMG, Pinheiro RR, Vitor RWA. Risk factors for infection by Toxoplasma gondii in herds of goats in Ceará, Brazil. Arq Bras Med Vet Zootec 2008; 60(1): 36-41. http://dx.doi.org/10.1590/S0102-09352008000100006.

Dean AG, Dean JA, Coulombier D, Brendel KA, Smith DC, Burton AH, et al. Epilnfo, Version 6: a word processing, data bases, and statistic program for epidemiology on microcomputers. [online]. Atlanta, Georgia: Center for Diseases Control and Prevention; 1996 [cited 2016 Feb 15]. Available from: https://stacks.cdc.gov/view/cdc/23189

Díaz JM, Fernández G, Prieto A, Valverde S, Lago N, Díaz P, et al. Epidemiology of reproductive pathogens in semi-intensive lambproducing flocks in North-West Spain: a comparative serological study. Vet J 2014; 200(2): 335-338. http://dx.doi.org/10.1016/j. tvjl.2014.02.022. PMid:24685472.

Dubey JP, Lindsay DS. A review of Neospora caninum and neosporosis. Vet Parasito/ 1996; 67(1-2): 1-59. http://dx.doi.org/10.1016/ S0304-4017(96)01035-7. PMid:9011014.

Dubey JP, Murata FHA, Cerqueira-Cezar CK, Kwok OCH, Su C. Economic and public health importance of Toxoplasma gondii infections in sheep: 2009-2020. Vet Parasito/ 2020; 286: 109195. http://dx.doi.org/10.1016/j.vetpar.2020.109195. PMid:32979682.

Dubey JP, Schares G, Ortega-Mora LM. Epidemiology and Control of Neosporosis and Neospora caninum. Clin Microbiol Rev 2007; 20(2): 323-367. http://dx.doi.org/10.1128/CMR.00031-06. PMid:17428888.

DubeyJP, Schares G. Neosporosis in animals - the last five years. Vet Parasito/ 2011; 180(1-2): 90-108. http://dx.doi.org/10.1016/j. vetpar.2011.05.031. PMid:21704458. 
Environmental Systems Research Institute - ESRI. ArcGIS Desktop: Release 10. Redlands, CA: Environmental Systems Research Institute; 2011.

Freyre A, Bonino J, Falcón J, Castells D, Correa O, Casaretto A. The incidence and economic significance of ovine toxoplasmosis in Uruguay. Vet Parasitol 1999; 81(1): 85-88. http://dx.doi.org/10.1016/s0304-4017(98)00215-5. PMid:9950332.

Garcia JL, Navarro IT, Biazzono L, Freire RL, Guimarães JS Jr, Cryssafidis AL, et al. Protective activity against oocyst shedding in cats vaccinated with crude rhoptry proteins of the Toxoplasma gondii by the intranasal route. Vet Parasito/ 2007; 145(3-4): 197206. http://dx.doi.org/10.1016/j.vetpar.2007.01.007. PMid:17296268.

Garcia JL, Navarro IT, Ogawa L, Oliveira RC. Soroprevalência do Toxoplasmas gondii, em suínos, bovinos, ovinos e eqüinos e sua correlação com humanos, felinos e caninos, oriundos de propriedades rurais do norte do Paraná - Brasil. Cienc Rural 1999; 29(1): 91-97. http://dx.doi.org/10.1590/S0103-84781999000100017.

Garcia JL, Navarro IT, Vidotto O, Gennari SM, Machado RZ, da Luz Pereira AB, et al. Toxoplasma gondii: comparison of a rhoptryELISA with IFAT and MAT for antibody detection in sera of experimentally infected pigs. Exp Parasitol 2006; $113(2): 100-105$. http://dx.doi.org/10.1016/j.exppara.2005.12.011. PMid:16458299.

Gazzonis AL, Alvarez Garcia G, Zanzani SA, Ortega Mora LM, Invernizzi A, Manfredi MT. Neospora caninum infection in sheep and goats from north-eastern Italy and associated risk factors. Small Rumin Res 2016; 140: 7-12. http://dx.doi.org/10.1016/j. smallrumres.2016.05.010.

Gheller JM, Carniel R, Carrasco AOT, Seki MC. Occurrence and risk factors for Toxoplasma gondii and Neospora caninum in sheep of the Guarapuava region, Paraná, Brazil. Braz J Vet Res Anim Sci 2016; 53(2): 177-181. http://dx.doi.org/10.11606/issn.1678-4456. v53i2p177-181.

Ghoneim NH, Shalaby SI, Hassanain NA, Zeedan GS, Soliman YA, Abdalhamed AM. Comparative study between serological and molecular methods for diagnosis of toxoplasmosis in women and small ruminants in Egypt. Foodborne Pathog Dis 2010; 7(1): 17-22. http://dx.doi.org/10.1089/fpd.2008.0223. PMid:19743922.

Gondim LFP, McAllister MM, Gao L. Effects of host maturity and prior exposure history on the production of Neospora caninum oocysts by dogs. Vet Parasitol 2005; 134(1-2): 33-39. http://dx.doi.org/10.1016/j.vetpar.2005.06.011. PMid:16029931.

Hamilton CM, Katzer F, Innes EA, Kelly PJ. Seroprevalence of Toxoplasma gondii in small ruminants from four Caribbean islands. Parasit Vectors 2014; 7(1): 449. http://dx.doi.org/10.1186/1756-3305-7-449. PMid:25249175.

Instituto de Geografia E Estatística - IBGE. Sistema IBGE de Recuperação Automática. Pesquisa da pecuária municipal. Rio de Janeiro: IBGE; 2019 [cited 2021 Mar 17]. Available from: https://sidra.ibge.gov.br/tabela/3939\#resultado.

Jittapalapong S, Sangvaranond A, Pinyopanuwat N, Chimnoi W, Khachaeram W, Koizumi S, et al. Seroprevalence of Toxoplasma gondii infection in domestic goats in Satun Province, Thailand. Vet Parasitol 2005; 127(1): 17-22. http://dx.doi.org/10.1016/j. vetpar.2004.08.019. PMid:15619370.

Kuraa HM, Malek SS. Seroprevalence of Toxoplasma gondii in ruminants by using latex agglutination test (LAT) and enzyme-linked immunosorbent assay (ELISA) in Assiut governorate. Trop Biomed 2016; 33(4): 711-725. PMid:33579068.

Lugoch G, Noro M, de Andrade J. Metanálise da prevalência de toxoplasmose em gatos e ovinos no Brasil. J Vet Sci Public Health 2019; 6(1): 41-70. http://dx.doi.org/10.4025/revcivet.v6i1.41361.

Moreno B, Collantes-Fernández E, Villa A, Navarro A, Regidor-Cerrillo J, Ortega-Mora LM. Occurrence of Neospora caninum and Toxoplasma gondii infections in ovine and caprine abortions. Vet Parasitol 2012; 187(1-2): 312-318. http://dx.doi.org/10.1016/j. vetpar.2011.12.034. PMid:22260901.

Moura AB, Osaki SC, Zulpo DL, Marana ERM. Ocorrência de anticorpos contra Toxoplasma gondii em suínos e ovinos abatidos no município de Guarapuava, PR, Brasil. Rev Bras Parasitol Vet 2007; 16(1): 54-56. PMid:17588324.

Ogawa L, Navarro IT, Freire RL, Oliveira RC, Vidotto O. Ocorrência de anticorpos anti-Toxoplasma gondii em ovinos da região de Londrina no Estado do Paraná. Semina: Ciênc Agrár 2003; 24(1): 57-62. http://dx.doi.org/10.5433/1679-0359.2003v24n1 p57.

Paraná. Governo do Estado. Secretaria de Estado da Agricultura e do Abastecimento - SEAB/PR. Departamento de Economia Rural - DERAL. Números da Pecuária Paranaense [online]. Curitiba: SEAB; 2019 [cited 2021 Mar 17]. Available from: http://www. agricultura.pr.gov.br/system/files/publico/Conjuntura/nppr.pdf

Pinheiro JW Jr, Mota RA, Oliveira AA, Faria EB, Gondim LF, da Silva AV, et al. Prevalence and risk factors associated to infection by Toxoplasma gondii in ovine in the State of Alagoas, Brazil. Parasitol Res 2009; 105(3): 709-715. http://dx.doi.org/10.1007/s00436009-1472-3. PMid:19468755.

Rêgo WMF, Paula NRO, Vitor RWA, Silva RAB, Diniz BLM, Sousa MM, et al. Risk factors for Toxoplasma gondii infection in goats and sheep raised in the State of Piauí in northeast Brazil. Small Rumin Res 2016; 141: 17-23. http://dx.doi.org/10.1016/j. smallrumres.2016.04.010. 
Romanelli PR, Freire RL, Vidotto O, Marana ER, Ogawa L, de Paula VSO, et al. Prevalence of Neospora caninum and Toxoplasma gondii in sheep and dogs from Guarapuava farms, Paraná State, Brazil. Res Vet Sci 2007; 82(2): 202-207. http://dx.doi.org/10.1016/j. rvsc.2006.04.001. PMid:17266999.

Romanelli PR, Matos AMRN, Pinto-Ferreira F, Caldart ET, Oliveira JS, Anteveli G, et al. Toxoplasma gondii and Neospora caninum infections and factors associated in goats in the Paraná state, Southern Brazil. Rev Bras Parasito/ Vet 2020; 29(4): e003620. http:// dx.doi.org/10.1590/s1984-29612020076. PMid:33053053.

Soccol VT, de Castro EA, Gazda TL, Garcia G, Richartz RR, Dittrich RL. Ocorrência de anticorpos anti-Toxoplasma gondii em ovinos das áreas urbanas e periurbanas de Curitiba, Paraná. Rev Bras Parasito/ Vet 2009;18(Suppl. 1): 69-70. http://dx.doi.org/10.4322/ rbpv.018e1013. PMid:20040195.

Uzêda RS, Fernandez SY, Jesus EEV, Pinheiro AM, Ayres MCC, Spinola S, et al. Fatores relacionados à presença de anticorpos IgG anti-Toxoplasma gondii em caprinos leiteiros do Estado da Bahia. Rev Bras Saúde Prod Anim 2004; 5(1): 1-8.

Valencio BA, Alves BF, Bezerra RA, Vilela VLR, Feitosa TF, Amaku M, et al. Longitudinal study of Toxoplasma gondii antibodies in female lambs from Paraíba State, Brazil. Small Rumin Res 2020; 188: 106125. http://dx.doi.org/10.1016/j.smallrumres.2020.106125.

Verhelst D, De Craeye S, Vanrobaeys M, Czaplicki G, Dorny P, Cox E. Seroprevalence of Toxoplasma gondii in domestic sheep in Belgium. Vet Parasitol 2014; 205(1-2): 57-61. http://dx.doi.org/10.1016/j.vetpar.2014.07.001. PMid:25065982.

Viana JGA, Silveira VCP. Cadeia produtiva da ovinocultura no Rio Grande do Sul: um estudo descritivo. Rev Agro Meio Ambiente 2009; 2(1): 9-20. http://dx.doi.org/10.17765/2176-9168.2009v2n1p9-20.

Villagra-Blanco R, Barrantes-Granados O, Montero-Caballero D, Romero-Zúñiga JJ, Dolz G. Seroprevalence of Toxoplasma gondii and Neospora caninum infections and associated factors in sheep from Costa Rica. Parasite Epidemiol Control $2019 ; 4$ : e00085. http://dx.doi.org/10.1016/j.parepi.2019.e00085. PMid:30666319.

Vismarra A, Barilli E, Miceli M, Mangia C, Genchi M, Brindani F, et al. Toxoplasma gondii in the Cornigliese sheep breed in Italy: meat juice serology, in vitro isolation and genotyping. Vet Parasito/ 2017; 243: 125-129. http://dx.doi.org/10.1016/j.vetpar.2017.06.013. PMid:28807281.

Weigel RM, Siegel AM, Dyer D, Dubey JP. Risk factors for infection with Toxoplasma gondii for residents and workers on swine farms in Illinois. Am J Trop Med Hyg 1999; 60(5): 793-798. http://dx.doi.org/10.4269/ajtmh.1999.60.793. PMid:10344655. 